IZA DP No. 5622

\title{
Pre-Hire Factors and Workplace Ethnic Segregation
}

Magnus Strömgren

Tiit Tammaru

Maarten van Ham
Szymon Marcinczak

Olof Stjernström

Urban Lindgren

April 2011 


\title{
Pre-Hire Factors and Workplace Ethnic Segregation
}

\author{
Magnus Strömgren \\ Umeå University \\ Tiit Tammaru \\ University of Tartu \\ Maarten van Ham \\ University of St Andrews and IZA
}

Szymon Marcinczak

Umeå University

Olof Stjernström

Umeå University

Urban Lindgren

Umeå University

\section{Discussion Paper No. 5622}

April 2011

IZA

P.O. Box 7240

53072 Bonn

Germany

Phone: +49-228-3894-0

Fax: +49-228-3894-180

E-mail: iza@iza.org

Any opinions expressed here are those of the author(s) and not those of IZA. Research published in this series may include views on policy, but the institute itself takes no institutional policy positions.

The Institute for the Study of Labor (IZA) in Bonn is a local and virtual international research center and a place of communication between science, politics and business. IZA is an independent nonprofit organization supported by Deutsche Post Foundation. The center is associated with the University of Bonn and offers a stimulating research environment through its international network, workshops and conferences, data service, project support, research visits and doctoral program. IZA engages in (i) original and internationally competitive research in all fields of labor economics, (ii) development of policy concepts, and (iii) dissemination of research results and concepts to the interested public.

IZA Discussion Papers often represent preliminary work and are circulated to encourage discussion. Citation of such a paper should account for its provisional character. A revised version may be available directly from the author. 
IZA Discussion Paper No. 5622

April 2011

\section{ABSTRACT}

\section{Pre-Hire Factors and Workplace Ethnic Segregation}

In addition to neighbourhoods of residence, family and places of work play important roles in producing and reproducing ethnic segregation. Therefore, recent research on ethnic segregation and contact is increasingly turning its attention from residential areas towards other important domains of daily interethnic contact. The key innovation of this paper is to clarify the role of immigrants' pre-hire exposure to natives in the residence, workplace and family domains in immigrant exposure to natives in their current workplace. The study is based on Swedish population register data. The results show that at the macro level, workplace neighbourhood segregation is lower than residential neighbourhood segregation. Our micro-level analysis further shows that high levels of residential exposure of immigrants to natives help to reduce ethnic segregation at the level of workplace establishments as well.

JEL Classification: J15, J61, R23

Keywords: neighbourhood effects, residential segregation, workplace segregation, intermarriage, longitudinal analysis, Sweden

Corresponding author:

Magnus Strömgren

Department of Social and Economic Geography

Umeå University

SE-901 87 Umeå

Sweden

E-mail: magnus.stromgren@geography.umu.se 


\section{INTRODUCTION}

Studies on ethnic residential segregation tend to privilege the time people spend at home and in the neighbourhood (Ellis et al, 2004). The neighbourhood is an important arena for daily interaction and provides a collective milieu that has an influence on social interactions. Residential neighbourhoods may therefore be important in the learning processes that help immigrants to master the challenges of living in a new country (Bauder, 2001; Blasius et al, 2007; Bolt and van Kempen, 2010; Feijten and van Ham, 2009; Friedrichs et al, 2003; Miller et al, 2009; Wang, 2010). In particular, living with natives in a neighbourhood has been found to positively affect immigrant labour market outcomes such as getting a job or having a higher income (Musterd et al, 2008; Tammaru et al, 2010).

Ethnic segregation takes place not only in neighbourhoods but also in other domains of daily life, including places of work. These other domains are also likely to influence the learning processes that help immigrants to integrate in their new society, including the host country's labour market (Amin, 2002; Bauder, 2001; Reskin et al, 1999; Tammaru et al, 2010; Wang, 2010). For example, while living with natives in a neighbourhood has been found to be associated with higher immigrant earnings, working with natives is an even more important factor in increasing immigrant earnings (Tammaru et al, 2010). Despite the evidence that ethnic segregation at workplaces matters, we know relatively little about the factors that influence workplace segregation.

Previous studies show that ethnic segregation at places of work is a persistent phenomenon, influenced by both pre-hire and post-hire factors (Becker, 1980; Mouw, 2002; Pred, 2000; Reskin et al, 1999; Sørensen, 2004). Pre-hire factors are those that precede the matching of people with jobs, while post-hire factors relate to in situ forces operating at places of work, such as different career prospects for those already employed. Both are important in understanding ethnic segregation at workplaces. Despite the theoretical interest in pre-hire factors, most empirical studies deal with post-hire factors (Sørensen, 2004). An important reason for this is a lack of suitable longitudinal data on pre-hire information. One of the key pre-hire mechanisms that generates segregation at places of work relates to ethnic residential segregation and how it affects the matching of workers to jobs (Ellis et al, 2004; Holzer, 1991; Kaufman 2002). A study by Bayer et al (2005) found that living in the same census tract increases the probability of working together. Ellis et al (2004) discovered that residential segregation by census tract accounts for over 40 per cent of the variance in work tract segregation, forming the most important factor in generating ethnic segregation at places of work. This result was confirmed by Wright et al (2010). It follows that ethnic segregation in one important domain of daily interaction, such as residential neighbourhood, could generate segregation in other important domains of daily interaction, such as place of work.

The aim of the current paper is to increase our understanding of the effects of previous exposure ${ }^{1}$ of immigrants to natives in the workplace, residence and family contexts on their exposure to natives in their current place of work. We are thus interested in how different domains of daily interaction are associated with the probability of immigrants working with natives. This study makes three relevant

\footnotetext{
${ }^{1}$ According to Massey and Denton (1988), residential exposure refers to spatial proximity or to the degree to which immigrants share a neighbourhood with the native population. Exposure thus measures the potential contact, or the probability of interaction, between immigrants and natives (Wilkes and Iceland, 2004).
} 
contributions to the existing body of research in this field. First, we define places of work at two different spatial/conceptual levels, both as workplace neighbourhoods and as establishments/plants. Previous studies explicitly studying the effects of ethnic residential segregation on ethnic segregation at places of work define the latter either as workplace neighbourhoods ${ }^{2}$ (e g Ellis et al, 2004; Wright et al, 2010) or as establishments (e g Hellerstein et al, 2008). Second, we not only investigate the effects of neighbourhood segregation on workplace segregation but also take into account segregation at the household level. This is important since living in a union with a native could facilitate more contacts with the majority population than living with a co-ethnic, making it easier to learn the new language, pick up the unwritten rules of society and establish oneself on the labour market (Dribe and Lundh, 2008; Ellis et al, 2004; Kantarevic, 2005; Meng and Meurs, 2009). Previous research has established that intermarriage is closely related to living outside co-ethnic neighbourhoods (Ellis et al, 2006; Tammaru and Kontuly, 2010). Third, we apply a longitudinal research design, using register-based data including the whole Swedish population. This design allows us to follow the immigrant cohorts that arrived in 1990, 1995 and 2000 during their first five years after arrival in Sweden. The data include detailed information on residence, family and workplace contexts.

\section{LITERATURE REVIEW}

Previous studies show that other domains of daily interaction, residence and family contexts could be important independent determinants of the ethnic composition of workplaces of immigrants (Ellis et al, 2004; Reskin et al, 1999; Sørensen, 2004; Wang, 2010). In many Western European countries, ethnic residential segregation has persisted despite several desegregation policy efforts in the host countries (Andersson et al, 2010; Bolt et al, 2010). This has been attributed to three main complementary explanations: immigrants' lack of economic resources in order to live in the same neighbourhoods as natives, especially when they arrive from less affluent countries as is often the case; discriminatory practices on the housing market imposed in the host country; and residential preferences among immigrants to live with co-ethnics (Semyonov and Glikman, 2009). Although immigrants have to find a place of residence from the very first day they arrive in their new homeland, only a small share of them start working immediately (Hedberg and Tammaru, 2010). As a result, the residential context after arrival is likely to have an important effect on job search behaviour and labour market outcomes (Bauder, 2001; Ellis et al, 2004).

The literature on neighbourhood effects further suggests that otherwise similar individuals may experience different labour market outcomes depending on the neighbourhood characteristics of residence (Andersson and Subramanian, 2006; Beggs et al, 1997; Borjas, 1995; Durlauf, 2004; Propper et al, 2007). Although the importance and magnitude of neighbourhood effects and the causal mechanisms underlying them are heavily debated (Van Ham and Manley, 2010), there are three partly overlapping explanations that provide insight into how residential segregation could contribute to workplace segregation. These are the proximity, network and cultural identification effects (Bauder, 2001; Edin et al, 2003; Ellis et al, 2004; Hellerstein et al, 2008; Liu, 2009). The proximity effect suggests that job searches

\footnotetext{
2 Most commonly, these are census tracts in the US context, and SAMS areas in the Swedish context (cf. Musterd et al, 2008; Tammaru et al, 2010).
} 
closer to home are more frequent due to lower search costs. Moreover, accepting job offers further away is likely to be subject to time and financial constraints (Hägerstrand, 1970; Miller, 1991; Neutens et al, 2011; Pred, 1977; 1981). Therefore, it is reasonable to argue that the probability of accepting job offers decreases with distance (Ellis et al, 2004; Holzer, 1996). Ethnic enterprises often operate in ethnic residential areas, providing local jobs for immigrants (Edin et al, 2003; Ellis et al, 2007; Li, 1998; Liu, 2009; Wright et al, 2010), thus linking residential segregation with workplace segregation.

The network effect implies that immigrants could improve their labour market outcomes by helping to disseminate valuable information on job opportunities among members of the co-ethnic group (Edin et al, 2003; Hellerstein et al, 2008). This could be especially important for recent immigrants who are starting to establish themselves in their new homeland. It should be acknowledged that the ethnic networks could also reach across neighbourhood borders, linking spatially fragmented immigrant communities in metropolitan space (Ellis et al, 2007; Liu, 2009).The cultural identification effect suggests that everyday practices are related to a reservoir of symbols, meanings and expectations embedded in local neighbourhoods (Bauder, 2001 ; 2002). For example, the stigmatisation of certain lower-income and immigrantdense neighbourhoods could limit the employment opportunities of the people living there (cf. Friedrichs et al, 2003). Likewise, images of different jobs could differ by ethnic neighbourhood context, constructed through everyday local practices, socialisation and institutions such as schools and other places where people meet on a frequent basis (Bauder, 2001; Wial, 1991). According to Bauder (2001, p. 46), "cultural differentiation, residential segregation and economic segmentation are interlocking processes in the production and reproduction of inequality".

Thus, ethnic residential segregation seems to reproduce segregation at places of work, but there is no one-to-one relationship between the two. Further, there are also forces related to the labour market and employment opportunities that could potentially lead immigrants away from ethnic areas, and contribute to the formation of less segregated workplaces compared to residential ethnic segregation in neighbourhoods. Two factors are of particular importance. The first is that jobs cannot always be found near places of residence. According to spatial mismatch research, the pattern of employment opportunities does not follow the residential patterns of immigrants, with jobs being more dispersed in metropolitan space compared to immigrants' places of residence (Ellis et al, 2004; Ihlanfeldt and Sjoquist, 1998; Johnston-Anumonwo, 2001). Immigrants might commute to work because their skills do not fit the requirements of jobs close to home, or there could be competition for the same jobs between different ethnic groups (Andersson et al, 2007; Ellis et al, 2004; Wright et al, 2010). Second, laws that regulate discrimination by promoting equal opportunity and affirmative action have also diversified the ethnic makeup at the establishment level (Estlund, 2003; Holzer and Neumark, 2000; Houston et al, 2005). For example, a study in the US by Holzer and Neumark (1999) suggests that the employment of white males among employers practicing affirmative action is roughly 15 per cent lower, corresponding to a similar increase in employment of white females and black males.

To conclude, the literature review reveals that ethnic residential segregation is a potentially important factor in generating ethnic segregation at places of work - at both the workplace neighbourhood and establishment levels. However, employment opportunities can also lead immigrants out of ethnic concentration neighbourhoods. The chances of meeting and interacting with people of different ethnic backgrounds 
are greater in workplaces relative to neighbourhoods of residence (Houston et al, 2005; Wellman, 1996). Greater inter-ethnic contact generally leads to lower levels of ethnic prejudice and stereotyping (Pettigrew, 1998; Pettigrew and Tropp, 2008), both potentially important for improving immigrants' labour-market outcomes (Tammaru et al, 2010). Finally, the family domain should be considered as well. Most neighbourhood effects literature does not take into account the ethnic composition of households, which may be associated with independent effects on workplace segregation. Thus, further work is needed on how different domains of daily interaction - residence, family and work - are linked together in producing and reproducing ethnic segregation at workplaces.

\section{DATA AND METHODS}

Our research population comprises immigrants to Sweden during the years 1990, 1995 and 2000. The micro data used originate from the Swedish population register, and extraction criteria specified that the immigrants should: be born outside Sweden; not be a Swedish citizen in the year of immigration; be aged 18-62 years in the year of immigration; not be reported deceased during the following five years; and not have immigrated during a previous study year. A total of 86,190 individuals (1990: $34,901 ; 1995: 23,513 ; 2000: 27,776)$ met these criteria. In our analyses we investigate the ethnic composition of workplaces five years after the immigrants arrived (in 1995, 2000 and 2005, respectively). At that time, 76 per cent of the initial population $(65,522$ people) were still residing in Sweden; and 55 per cent $(35,810)$ of those in Sweden were on the labour market.

We define places of work both as workplace neighbourhoods and as establishments of work. Conceptualising places of work as workplace neighbourhoods offers the opportunity to study the overall ethnic context of the area where people work, and allows us to explicitly compare levels of exposure to natives in residential and workplace neighbourhoods (Wright et al, 2010). In the macro-level part of the study we use neighbourhoods as the level of analysis. Thinking of workplaces as establishments where co-workers meet on a daily basis offers the opportunity to focus on the potential of daily contact between immigrants and natives. Previous studies show that higher shares of natives at establishments are associated with higher earnings for immigrants, most likely stemming from learning processes at places of work (Tammaru et al, 2010). We use establishment-level definitions of places of work in the micro-level analysis to clarify how previous exposure to natives in residential neighbourhoods, workplace establishments and families is associated with current exposure of immigrants to natives at establishments. Observations in this part of the paper refer to individuals.

\section{Macro-level analysis}

We start our analysis by computing indices of immigrant exposure to members of the native population in residential and workplace neighbourhoods. Since 1988, when the seminal paper by Massey and Denton was published, segregation has been conceptualised as a multidimensional process. Although the five-dimensional notion proposed by Massey and Denton (1988) has recently been contested and more simplified models have been suggested (Brown and Chung, 2006; Johnston et al, 2007; Reardon and O'Sullivan, 2004; Wong 2008), the exposure dimension of segregation is still highly relevant. This dimension essentially relates to the degree of 
potential contact, or the possibility of interaction, between minority and majority groups within geographical areas of a city or other region (Massey and Denton, 1988). Currently, the most widely used measure of the exposure dimension of segregation is the $P^{*}$ index proposed by Lieberson (1981). The index describes the isolation of a group and its potential interaction with another group in a manner that takes into account both the spatial dissimilarity and the relative sizes of the groups in the region (Lieberson and Carter, 1982).

There are two basic versions of $P^{*}$. The major difference between them is whether the interaction is measured between members of the same social/ethnic groups (isolation) or between members of two different social/ethnic groups (exposure). Bearing in mind that the focus of this contribution is on the level of exposure of newly arrived immigrants to native Swedes at places of work, we decided to limit the global analysis of residential and workplace segregation to the exposure index. This choice was also influenced by the next stages of our empirical inquiry, particularly the form of the dependent variable used in the multinomial regression model (see next subsection). The exposure index $\left({ }_{x} P_{y}^{*}\right)$ expresses the probability that members of a social/ethnic group $X$ will share neighbourhoods with people from group $\mathrm{Y}$. The index is computed as:

${ }_{x} P_{y}^{*}=\sum_{i}\left|\left(\frac{x_{i}}{X}\right) \times\left(\frac{y_{i}}{t_{i}}\right)\right|$

where $x_{i}$ is the number of members of group $\mathrm{X}$ in an areal unit/neighbourhood $i ; X$ represents the total population of the group in all neighbourhoods; $y_{i}$ is the number of members of group $\mathrm{Y}$ in neighbourhood $i$; and $t_{i}$ is the total population in neighbourhood $i .{ }_{x} P_{y}^{*}$ ranges from zero (complete segregation since there are no members of group Y living in neighbourhoods where members of X are found) to Y's proportion of the total population (in which case there is no segregation between $\mathrm{X}$ and $\mathrm{Y}$ because $\mathrm{Y}$ 's proportion in each neighbourhood where members of $\mathrm{X}$ are found is identical to Y's proportion in the total population). Therefore, this index is asymmetric; except in cases when the two groups comprise the same proportion of the total population, ${ }_{x} P_{y}^{*}$ does not equal ${ }_{y} P_{x}^{*}$. We use SAMS areas to study both residential and workplace exposure in order to get comparable measures at the macro level. SAMS is a spatial subdivision of Sweden, based mainly on municipal planning zones and voting districts, which aims to define homogenous residential neighbourhoods. In total, there are 9,208 such neighbourhoods in Sweden. In 2005, the average population at the SAMS level was just below 1,000 inhabitants.

We should recall that $P^{*}$ is sensitive to the relative size of subgroups. In other words, if a minority group accounts for a small proportion of the total population, there is a greater possibility that people from this group will be exposed to the majority population. Conversely, if a minority group constitutes a relatively large proportion of the population, it is likely that people from this group will be less exposed to the majority (Blau, 1977). Therefore, if used in comparative studies, $P^{*}$ should be interpreted relative to the percentage size that the concerned groups form of the total population in order to avoid misleading conclusions (Cutler et al, 1999; Peach, 2009). In addition, the maximum value of $P^{*}$ is context-bound; in our case, the share of native Swedes constitutes its maximum value. For instance, if the share of native Swedes in a certain region is 70 per cent for a particular year, the maximum exposure that is possible given the circumstances is 0.7 . Since the share of foreignborn has increased over time in Sweden, this structural change in population 
composition will, ceteris paribus, contribute to lower exposure over time. A modified, standardised version of ${ }_{x} P_{y}^{*}$ that always ranges from zero to one takes the following form:

$M_{x} P_{y}^{*}=1-\left({ }_{x} P_{y}^{*} /\left(\frac{Y}{T}\right)\right)$

where ${ }_{x} P_{y}^{*}$ is the exposure index; $Y$ represents the total population of group $\mathrm{Y}$ in all neighbourhoods; and $T$ is the total population in all neighbourhoods. Similar to the modified index of isolation (cf. Johnston and Jones, 2010), $M_{x} P_{y}^{*}$ can be interpreted as a measure of the relative gap between the actual exposure of group $\mathrm{X}$ to $\mathrm{Y}$ and the exposure that would be experienced if group $\mathrm{Y}$ were uniformly distributed across a region. In other words, the higher the value of $M P^{*}$ the lower the actual, experienced exposure compared to the exposure that is possible to achieve, given the population composition at a particular point in time and space.

We believe that both $P^{*}$ and $M P^{*}$ convey meaningful information on immigrant exposure to the native population, and therefore use both indices in our empirical analysis. Adjusted and unadjusted indices of exposure are calculated for each immigrant cohort every five years. We compute separate indices for the different levels of the settlement system, as well as depending on the origin of the immigrants: either Global North (GN) - Europe and North America - or Global South (GS) the Middle East, Asia, Africa and South America (Tammaru et al, 2010). The index values are multiplied by 100 and rounded to the closest integer, in order to make the presentation of the results more legible.

\section{Micro-level analysis}

We use a micro-level model to investigate the effects of previous exposure of immigrants to native Swedes in establishments, neighbourhoods of residence and family on their exposure to native Swedes in their current workplace establishment. This analysis forms the core of the current study. Our dependent variable measures the share of Swedes at the establishment where immigrants work five years after their arrival in Sweden. Since many immigrants work with other immigrants only, we aggregated this linear variable into meaningful groups (cf. Kanter, 1977). There are few establishments where immigrants themselves are the dominant group, so we aggregated the lower end of the distribution into larger categories. Conversely, since most immigrants are employed by establishments with a relatively high share of Swedes, we split the higher end of the distribution into smaller categories. This resulted in the following dependent variable categories: $0 \%, 1-39 \%, 40-69 \%, 70-$ $79 \%, 80-89 \%, 90-99 \%$ share of Swedes at establishments where immigrants work. The distribution of immigrants across these categories is displayed in table 1 .

\section{$<$ TABLE 1 about here $>$}

Of our initial research population of 86,190 immigrants, 35,810 were still residing in Sweden and in employment five years after arrival. However, in order to establish a causal relationship between the exposure variables and the dependent variable, we measured exposure of immigrants to natives only for the period prior to their being hired at the job held five years after arrival. The drawback of this research design is that the research population is reduced to the 22,432 individuals who have pre-hire workplace exposure. Missing or ambiguous values for the dependent and independent 
variables further reduced the research population to 19,095 people. The residence domain is represented by a variable measuring the share of Swedes in the neighbourhood, where a neighbourhood is defined as a SAMS area. The work domain is represented by a variable measuring the share of Swedes in the establishment where an immigrant works. These are actual and geocoded places of work, which allows us to better capture the (1) immediate ethnic context of immigrant workplaces, and (2) the probability that immigrants will come into contact with native Swedish coworkers. Since immigrants may change neighbourhoods and workplaces over time, the variables measure the average annual exposure to natives over the pre-hire period. The family domain is represented by a measure of Swedish partner years, which measures the number of pre-hire years an immigrant has lived with a native partner. ${ }^{3}$ We use multinomial regression to investigate how the pre-hire exposure of immigrants to the native population influences the current ethnic composition at their workplace establishments. The regression equation is as follows:

$P\left(y_{i}=j\right)=\frac{\exp \left(X_{i} \beta_{j}\right)}{1+\sum_{j=1}^{J} \exp \left(X_{i} \beta_{j}\right)}$

where $P\left(Y_{i}=j\right)$ is an individual's $i=1, \ldots I$ probability of working in establishments with various shares of Swedes $(j=1$ if $0 \%, j=2$ if $1-39 \%, j=3$ if $40-69 \%, j=4$ if $70-79 \%$, $j=5$ if $80-89 \%, j=6$ if $90-99 \%$ ). We choose $j=2$ as a reference category and compute the relative risks for all other categories since $j=1$ is a very special case, in which all co-workers are immigrants (cf. Kanter, 1977). $X_{i}$ is the value of the variable for an individual; and $\beta_{j}$ is the parameter describing the effect of this variable. We study three immigrant cohorts who arrived in Sweden in 1990 (economic depression), 1995 (economic improvement) and 2000 (good macroeconomic environment) to control for the impact of the economic context at the time of arrival on exposure to natives at establishments. We include several other control variables in our models that take into account the origin of immigrants, human capital characteristics and other variables reflecting neighbourhood and establishment characteristics (table 1). As in the macrolevel analysis, a distinction is made between immigrants originating from Global North (GN) and Global South (GS).

\section{RESULTS}

\section{Macro-level analysis of residential and workplace exposure to natives}

The results of the macro-level residential segregation analysis reveal that GN immigrants' scores of exposure are higher than those of GS immigrants (table 2). Compared to GS immigrants, newcomers from GN countries usually settle in neighbourhoods where a larger share of the population is Swedish. This pattern is stable and applies to all three studied cohorts. The differences between GN and GS immigrants are in line with previous studies carried out in Sweden (Andersson, 1998; Bråmå, 2008), and confirm the existence of an "ethnic hierarchy". More "obvious" minorities, especially those from Africa and the Middle East, are less exposed to

\footnotetext{
${ }^{3}$ By "native partner" we mean a partner born in Sweden. It should also be noted that in the population register, cohabiting couples without joint children are treated as singles. Hence, the partner year variable comprises a subset of all actual partnerships, i.e. those involving legal marriage or cohabitation with joint children.
} 
native Swedes in their neighbourhoods than less obvious minorities are. Murdie and Borgegård (1998) attribute this to differences in language and lifestyle, as there is a considerable social distance between immigrants from GS countries and native Swedes.

\section{$<$ TABLE 2 about here $>$}

Both GN and GS immigrants experience a decreasing level of exposure to natives during the first five years after their arrival in Sweden (table 2). However, it is unclear from this macro-level data whether this is due to their migration to more ethnically segregated neighbourhoods or to the impact of new immigrants who tend to settle in similar destinations as previous immigrants have. After ten to fifteen years in Sweden, the level of exposure to the native population tends to stabilise and in some cases slowly increases. Generally, the GN immigrants have a higher exposure to Swedes at all levels of the settlement system except regions outside metropolitan areas and larger regional centres, $i$ e the group labelled "Rest of Sweden" in table 2. It also seems that both GN and GS immigrants are less exposed to the native Swedish population in the metropolitan areas - Stockholm, Gothenburg and Malmö - than in the other parts of Sweden.

Immigrants' exposure to native Swedes is considerably higher at the workplace neighbourhood level, compared to that in residential neighbourhoods. The patterns of workplace exposure show an ethnic hierarchy similar to those of residential exposure to natives, in that GN immigrants' exposure scores are higher than those of the GS immigrants (table 2). However, the difference between the two origin categories is much less pronounced. This confirms the results of previous studies carried out in the US context (Bayer et al, 2005; Ellis et al, 2004; Wright et al, 2010). As with residential exposure, both GN and GS immigrants are less exposed to the native Swedish population in the metropolitan areas compared to other parts of Sweden. Furthermore, in all cohorts, the level of exposure to Swedes in workplace neighbourhoods starts to increase as the length of stay in Sweden increases. Finally, we can observe that standardised workplace exposure indices are very low compared to the corresponding neighbourhood exposure indices (table 3). It follows that the actual exposure is closer to the empirical maximum in workplace neighbourhoods compared to residential neighbourhoods. This implies that workplaces facilitate ethnic desegregation more effectively than places of residence do.

\section{$<$ TABLE 3 about here $>$}

\section{Micro-level analysis of workplace exposure to natives}

Using individual-level data, we modelled the relationship between immigrants' previous exposure to natives and their probability of working with natives five years after their arrival in Sweden. Workplaces are defined as establishments in this part of the study. The Nagelkerke pseudo $R^{2}$ of the multinomial logistic regression is 0.400 . The results of the regression (table 4) show that higher previous exposure in all three domains of daily interaction independently, and in a linear fashion, elevate the probability of working with natives, even after controlling for other important individual characteristics. There is just one exception to this pattern: Immigrants working in exclusively ethnic establishments with no native colleagues ( $0 \%$ exposure) do not differ in the way we expected them to from those working in the reference category (1-39\% exposure). Immigrants in these ethnically uniform workplaces are in 
many cases self-employed. However, immigrants in the reference category differ in the expected way from those in all the higher-order exposure categories. Thus, it is safe to conclude that the higher the number of years with a native partner, the higher the share of natives in the neighbourhood of residence and the higher the share of natives at previous workplace establishments, the higher the probability is that immigrants will work with Swedes at the current establishment. For example, our results indicate that every percentage point increase in the share of Swedes in an immigrant's residential neighbourhood elevates his/her odds of working at an establishment with 90 per cent or more Swedes by 4 per cent.

\section{$<$ TABLE 4 about here $>$}

The control variables in the model show that there are no systematic differences between immigrant cohorts in workplace exposure to natives. The gender effect shows that men are more likely than women to work in exclusively ethnic establishments ( $0 \%$ exposure). We found interesting results for establishments where natives are over-represented (the 70-89\% and 90-99\% exposure categories) concerning age and education. Older immigrants, independent of their year of arrival, are less likely to work in such workplaces, while university-educated immigrants are more likely to.

We also found interesting effects of origin and region of residence on workplace exposure to natives. First, and as expected, we found that immigrants from GS countries are more likely to work in ethnic work establishments $(0 \%$ and $1-39 \%$ exposure to natives) compared to immigrants from GN countries. The odds of working in a particular establishment decrease in a linear fashion as the share of Swedes in the workplace increases. This implies that GS immigrants have difficulties finding their way to work establishments with mainly native workers. Second, place of residence in the Swedish settlement system is systematically related to segregation at places of work as well. In Stockholm, immigrants are relatively commonly found in establishments that are not exclusively ethnic, but where ethnic minorities are overrepresented (1-39\% exposure). In other parts of Sweden, a U-shaped pattern emerges relative to Stockholm: Immigrants cluster either into ethnic workplaces or into those where Swedes are over-represented. For example, in regions outside metropolitan areas and larger regional centres (the "Rest of Sweden" category in table 3) immigrants have 2.5 times higher odds of working in exclusively ethnic establishments ( $0 \%$ exposure) and 6.8 times higher odds of working in establishments with a share of natives between 90 and 99 per cent relative to immigrants working in Stockholm.

The probability of working with native Swedes is highly related to an immigrant's employment sector. Immigrants working in private sector enterprises often work with other immigrants, while working in municipal workplaces significantly elevates the probability of working with Swedes. This probability increases even further for immigrants employed in the state sector. Furthermore, the number of years employed in Sweden is linearly related to the probability of working with Swedes. For example, every year in employment increases the probability of working at establishments with 90 per cent or more Swedes by 16 per cent. This implies that many immigrants start their working careers in ethnic workplaces, and subsequently move to less segregated workplaces. Thus, the initial finding of a decrease in neighbourhood workplace exposure over time (table 2) is likely the result 
of new immigrants entering the labour market, while those already employed move away from ethnic establishments, lowering ethnic segregation at places of work.

\section{CONCLUSIONS AND DISCUSSION}

Studies on ethnic segregation tend to privilege the time when people are at home. Yet there are other domains of daily interaction, such as places of work and family, that play an important role in producing and reproducing ethnic segregation. The key innovation of this paper is that it clarifies the role of pre-hire exposure of immigrants to natives at places of residence and work, and in the family, in immigrant exposure to natives in their current workplace - capitalising on the longitudinal and georeferenced data of the Swedish population register. The study focused, first, on the macro-level or structural patterns of segregation. The results confirmed findings of previous studies (Ellis et al, 2004; Wright et al, 2010) that workplace neighbourhood segregation is lower than residential neighbourhood segregation.

The micro-level analysis revealed that a high level of residential exposure of immigrants to natives in residential neighbourhoods reduces ethnic segregation at the level of workplace establishments as well. To confirm this effect, we controlled for partner origin as well since partners share neighbourhood of residence. The results showed that the positive neighbourhood effect (living with natives) remains, and that a further positive effect arises from living with a native partner. It follows that various domains of daily interaction are positively related to each other, facilitating ethnic desegregation at places of work. The latter, in turn, has a positive impact on the development of immigrant earnings (Tammaru et al, 2010).

These results have important implications in terms of spatial policies of immigrant residential placement upon arrival; it is safe to argue that residential desegregation policies could make an important contribution to increasing immigrant welfare in host countries. Immigrants start living somewhere from their very first day of arrival, and their initial settlement pattern tends to change little over time (Hou, 2007). However, finding a job takes more time (Chiswick et al, 1997; Hedberg, 2009); settling in non-ethnic residential areas thus facilitates finding a job in non-ethnic neighbourhoods and non-ethnic establishments (cf. Bauder, 2001). While pre-hire neighbourhood exposure to natives exerts a modest positive effect on immigrant earnings, pre-hire exposure to natives at places of work is a more important factor in this respect, especially for immigrants arriving from GS countries (Tammaru et al, 2010). Thus, lower levels of ethnic residential segregation upon arrival would facilitate lower levels of ethnic segregation at places of work that, in turn, are positively related to immigrant earnings and to their economic advancement in the host country.

\section{Acknowledgements}

We acknowledge the financial support provided by the Umea SIMSAM NodeRegister-based Research Programme Connecting Childhood with Lifelong Health and Welfare (funded by the Swedish Research Council), and the NORFACE research programme on Migration in Europe-Social, Economic, Cultural and Policy Dynamics. 


\section{REFERENCES}

Amin A, 2002, "Ethnicity and the multicultural city: living with diversity" Environment and Planning A 34959 - 980

Andersson R, 1998, "Socio-spatial dynamics: ethnic divisions of mobility and housing in post-Palme Sweden" Urban Studies 35397 - 428

Andersson E, Subramanian S V, 2006, "Explorations of neighbourhood and educational outcomes for young Swedes" Urban Studies 432013 - 2025

Andersson R, Musterd S, Galster G, Kauppinen T M, 2007, "What mix matters? Exploring the relationships between individuals' incomes and different measures of their neighborhood context" Housing Studies 22637 - 660

Andersson R, Bråmå Å, Holmqvist E, 2010, "Counteracting segregation: Swedish policies and experiences" Housing Studies 25237 - 256

Bauder H, 2001, "Culture in the labor market: segmentation theory and perspectives of place" Progress in Human Geography 2537 - 52

Bauder H, 2002, "Neighbourhood effects and cultural exclusion" Urban Studies 3985 $-93$

Bayer P, Ross S, Topa G, 2005, Place of Work and Place of Residence: Informal Hiring Networks and Labor Market Outcomes NBER Working Papers w11019, National Bureau of Economic Research, Cambridge, MA

Becker H J, 1980, "Racial segregation among places of employment" Social Forces $58761-76$

Blasius J, Friedrichs J, Galster G, 2007, “Introduction: frontiers of quantifying neighbourhood effects" Housing Studies 22627 - 636

Blau P M, 1977 Inequality and Heterogeneity: A Primitive Theory of Social Structure (The Free Press, New York, NY)

Beggs J, Villemez W, Arnold R, 1997, "Black population concentration and BlackWhite inequality: expanding the consideration of place and space effects" Social Forces $7665-91$

Bolt G, Phillips D, van Kempen R, 2010, "Housing policy, (de)segregation and social mixing: an international perspective" Housing Studies 25129 - 135

Bolt G, van Kempen R, 2010, "Ethnic segregation and residential mobility: relocations of minority ethnic groups in the Netherlands" Journal of Ethnic and Migration Studies 36333 - 354

Borjas G, 1995, "Ethnicity, neighborhoods, and human-capital externalities" American Economic Review 85365 - 390

Bråmå Å, 2008, "Dynamics of ethnic residential segregation in Göteborg, Sweden, 1995-2000" Population, Space and Place $14101-117$

Brown L A, Chung S-Y, 2006, "Spatial segregation, segregation indices and the geographical perspective" Population, Space and Place 12125 - 143

Chiswick B, Cohen Y, Zach T, 1997, "The labor market status of immigrants: effects of the unemployment rate at arrival and duration of residence" Industrial and Labor Relations Review 50289 - 303

Cutler D M, Glaser E L, Vigdor J L, 1999, "The rise and decline of the American ghetto" Journal of Political Economy 107455 - 506

Dribe M, Lundh C, 2008, "Intermarriage and immigrant integration in Sweden" Acta Sociologica $51329-354$

Durlauf S, 2004, "Neighborhood effects", in Handbook of Regional and Urban Economics: Volume 4, Cities and Geography Eds J V Henderson, J F Thisse (Elsevier, Amsterdam) pp 2173 - 2242 
Edin P-A, Fredriksson P, Åslund, O, 2003, "Ethnic enclaves and the economic success of immigrants: evidence from a natural experiment" Quarterly Journal of Economics 118329 - 357

Ellis M, Wright R, Parks V, 2004, "Work together, live apart? Geographies of racial and ethnic segregation at home and at work" Annals of the Association of American Geographers 94620 - 637

Ellis M, Wright R, Parks V, 2006, “The immigrant household and spatial assimilation: partnership, nativity, and neighborhood location" Urban Geography $2711-19$

Ellis M, Wright R, Parks V, 2007, "Geography and the immigrant division of labour" Economic Geography" 83255 - 281

Estlund C, 2003 Working Together: How Workplace Bonds Strengthen the Diverse Democracy (Oxford University Press, New York, NY)

Feijten P, van Ham M, 2009, "Neighbourhood change... reason to leave?" Urban Studies $462103-2122$

Friedrichs J, Galster G, Musterd S, 2003, "Neighbourhood effects on social opportunities: the European and North American context" Housing Studies 18 $797-806$

Hägerstrand T, 1970, "What about people in regional science?" Papers of the Regional Science Association 247 - 21

Hedberg C, 2009, "Entrance, exit and exclusion: labour market flows of foreign born adults in Swedish 'divided cities" Urban Studies 462423 - 2446

Hedberg C, Tammaru T, 2010, 'Neighbourhood effects' and 'City Effects': Immigrants' Transition to Employment in Swedish Large City-Regions SULCIS Working Papers 2010:6, Stockholm University Linnaeus Center for Integration Studies

Hellerstein J K, McInerney M, Neumark D, 2008, Neighbors and Co-Workers: The Importance of Residential Labor Market Networks NBER Working Papers w14201, National Bureau of Economic Research, Cambridge, MA

Holzer H J, 1991, "The spatial mismatch hypothesis: what has the evidence shown?" Urban Studies 28105 - 22

Holzer H J, 1996, What Employers Want: Job Prospects for Less-Educated Workers (Russell Sage Foundation, New York, NY)

Holzer H J, Neumark D, 1999, “Are Affirmative action hires less qualified? Evidence from employer-employee data" Journal of Labor Economics 17534 - 69

Holzer H J, Neumark D, 2000, “Assessing affirmative action” Journal of Economic Literature 38483 - 568

Hou F, 2007, "Changes in the initial destinations and redistribution of Canada's major immigrant groups: reexamining the role of group affinity" International Migration Review 41680 - 705

Houston S, Wright R, Ellis M, Holloway S, Hudson M, 2005, "Places of possibility: where mixed-race partners meet" Progress in Human Geography 29700 - 717

Ihlanfeldt K R, Sjoquist D L, 1998, "The spatial mismatch hypothesis: a review of recent studies and their implications for welfare reform" Housing Policy Debate $9849-892$

Johnston R J, Poulsen M, Forrest J, 2007, “The geography of ethnic residential segregation: a comparative study of five countries" Annals of the Association of American Geographers 97713 - 738

Johnston R J, Jones K, 2010, “Commentary” Environment and Planning A 421264 1270 
Johnston-Anumonwo I, 2001, "Persistent racial differences in the commutes of Kansas City workers" Journal of Black Studies 31651 - 670

Kantarevic J, 2005 Interethnic Marriages and Economic Assimilation of Immigrants DP1142, Institute for the Study of Labor, Bonn

Kanter R M, 1977, "Some effects of proportions on group life: skewed sex ratios and responses to token women" The American Journal of Sociology 82965 - 990

Kaufman R L, 2002," Assessing alternative perspectives on race and sex employment segregation" American Sociological Review 67547 - 72

Li W, 1998, "Anatomy of a new ethnic settlement: the Chinese ethnoburbs in Los Angeles" Urban Studies 35470 - 501

Lieberson S, 1981, “An asymmetrical approach to segregation", in Ethnic Segregation in Cities, Eds C Peach, V Robinson, S Smith (Groom Helm, London) pp. 61 82

Lieberson S, Carter D, 1982, "Temporal changes and urban differences in residential segregation: a reconsideration" The American Journal of Sociology 88296 310

Liu C Y, 2009, "Ethnic enclave residence, employment, and commuting of Latino workers" Journal of Policy Analysis and Management 28600 - 625

Massey D S, Denton N, 1988, "The dimensions of residential segregation" Social Forces $67281-315$

Meng X, Meurs D, 2009, "Intermarriage, language, and economic assimilation process: a case study of France" International Journal of Manpower 30127 144

Miller H J, 1991, "Modelling accessibility using space-time prisms concepts within geographical information systems" International Journal of Geographical Information Systems 5287 - 301

Miller A, Birman D, Zenk S, Wang E, Sorokoin O, Connor J, 2009, "Neighborhood immigrant concentration, acculturation, and cultural alienation in former Soviet immigrant women" Journal of Community Psychology 3788 - 105

Mouw T, 2002, "Are Black workers missing the connection? The effect of spatial distance and employee referrals on interfirm racial segregation" Demography $39507-528$

Murdie R, Borgegård L-E, 1998, "Immigration, spatial segregation and housing segregation of immigrants in Metropolitan Stockholm 1960-95" Urban Studies $351869-1888$

Musterd S, Andersson R, Galster G, Kauppinen T, 2008, “Are immigrants' earnings influenced by the characteristics of their neighbours?" Environment and Planning A 40785 - 805

Neutens T, Schwanen T, Witlox F, 2011, "The prism of everyday life: towards a new research agenda for time geography" Transport Reviews 3125 - 47

Peach C, 2009, "Slippery segregation: discovering or manufacturing ghettos?" Journal of Ethnic and Migration Studies 351381 - 1395

Pettigrew T F, 1998, "Intergroup contact theory” Annual Review of Psychology 4965 $-85$

Pettigrew T F, Tropp L R, 2008, “How does intergroup contact reduce prejudice? Meta analytic tests of three mediators" European Journal of Social Psychology $38922-934$

Pred A, 1977, "Choreography of existence: comments on Hägerstrand's timegeography and its usefulness" Economic Geography 53207 - 221 
Pred A, 1981, "Social reproduction and the time-geography of everyday life" Geografiska Annaler Series B 635 - 22

Pred A, 2000 Even in Sweden: Racisms, Racialized Spaces, and the Popular Geographical Imagination (University of California Press, Berkeley, CA)

Propper C, Burgess S, Bolster A, Leckie G, Jones K, Johnston R, 2007, “The impact of neighbourhood on the income and mental health of British social renters" Urban Studies 44393 - 415

Reardon S F, O'Sullivan D, 2004, "Measures of spatial segregation” Sociological Methodology $34121-162$

Reskin B F, McBrier D B, Kmec J A, 1999, "The determinants and consequences of workplace sex and race composition" Annual Review of Sociology 25335 - 361

Semyonov M, Glikman A, 2009, "Ethnic residential segregation, social contacts, and anti-minority attitudes in European societies" European Sociological Review 25 $693-708$

Sørensen J B, 2004, “The organizational demography of racial employment segregation" The American Journal of Sociology 110626 - 671

Tammaru T, Kontuly T, 2010, "Selectivity and destinations of ethnic minorities leaving the main gateway cities of Estonia" Population, Space and Place Published on-line 7 July 2010

Tammaru T, Strömgren M, Stjernström O, Lindgren U, 2010, "Learning through contact? The effects on earnings of immigrant exposure to the native population" Environment and Planning A 422938 - 2955

Van Ham M, Manley D, 2010, "The effect of neighbourhood housing tenure mix on labour market outcomes: a longitudinal investigation of neighbourhood effects" Journal of Economic Geography 10257 - 282

Wang G, 2010, "How does geography matter in the ethnic labor market segmentation process? A case study of Chinese immigrants in the San Francisco CMSA" Annals of the Association of American Geographers 100182 - 201

Wellman B, 1996, "Are personal communities local? A Dumptarian reconsideration" Social Networks 18347 - 354

Wial H, 1991, "Getting a good job: mobility in a segmented labor market" Industrial Relations 30396 - 416

Wilkes R, Iceland J, 2004, "Hypersegregation in the Twenty-first Century" Demography 4123 - 36

Wong D W S, 2008, “A local multidimensional approach to evaluate changes in segregation" Urban Geography 29455 - 472

Wright R, Ellis M, Parks V, 2010, "Immigrant niches and the intrametropolitan spatial division of labour" Journal of Ethnic and Migration Studies 361033 - 1059 
Table 1. Descriptive statistics for the micro-level research population.

\begin{tabular}{|c|c|c|c|c|c|c|}
\hline \multirow{2}{*}{\multicolumn{2}{|c|}{ Share of research population (row percentages) }} & $0 \%$ & $1-39 \%$ & $40-69 \%$ & $70-89 \%$ & $90-99 \%$ \\
\hline & & 10 & 9 & 20 & 41 & 20 \\
\hline \multicolumn{2}{|c|}{ Average share of Swedes in neighbourhood } & 77 & 72 & 76 & 80 & 86 \\
\hline \multicolumn{2}{|c|}{ Number of years with Swedish partner } & 0.6 & 0.5 & 0.7 & 0.8 & 0.9 \\
\hline \multicolumn{2}{|c|}{ Average share of Swedes at previous workplaces } & 39 & 45 & 59 & 71 & 80 \\
\hline \multirow[t]{3}{*}{ Year of immigration } & 1990 & 36 & 34 & 38 & 40 & 44 \\
\hline & 1995 & 28 & 32 & 31 & 31 & 29 \\
\hline & 2000 & 36 & 34 & 31 & 29 & 27 \\
\hline \multirow[t]{2}{*}{ Sex } & Female & 29 & 40 & 46 & 47 & 50 \\
\hline & Male & 71 & 60 & 54 & 53 & 50 \\
\hline \multirow[t]{3}{*}{ Age } & $23-34$ & 55 & 59 & 60 & 59 & 55 \\
\hline & $35-44$ & 32 & 30 & 29 & 31 & 32 \\
\hline & $45-67$ & 13 & 11 & 11 & 10 & 13 \\
\hline \multirow[t]{3}{*}{ Education } & Compulsory school & 33 & 34 & 27 & 19 & 16 \\
\hline & Upper secondary school & 34 & 38 & 39 & 36 & 35 \\
\hline & University & 33 & 28 & 34 & 45 & 49 \\
\hline \multirow[t]{2}{*}{ Country of origin } & Global North & 42 & 39 & 50 & 65 & 74 \\
\hline & Global South & 58 & 61 & 50 & 35 & 26 \\
\hline \multirow[t]{5}{*}{ Region of residence } & Stockholm metropolitan area & 43 & 65 & 57 & 43 & 22 \\
\hline & Gothenburg metropolitan area & 12 & 11 & 12 & 14 & 13 \\
\hline & Malmö metropolitan area & 13 & 9 & 11 & 11 & 10 \\
\hline & Larger regional centre & 23 & 12 & 14 & 24 & 39 \\
\hline & Rest of Sweden & 9 & 3 & 6 & 8 & 16 \\
\hline \multirow[t]{3}{*}{ Employment sector } & Private & 100 & 92 & 76 & 65 & 57 \\
\hline & Municipality & 0 & 7 & 19 & 25 & 33 \\
\hline & State & 0 & 1 & 5 & 10 & 10 \\
\hline \multicolumn{2}{|c|}{ Number of years in employment } & 3.5 & 3.6 & 3.8 & 3.8 & 4 \\
\hline \multicolumn{2}{|c|}{ Average neighbourhood population (ln) } & 7.9 & 8.1 & 8 & 7.8 & 7.6 \\
\hline \multicolumn{2}{|c|}{ Average number of colleagues at previous workplaces $(\ln )$} & 2.8 & 4 & 4.3 & 4.7 & 4.6 \\
\hline
\end{tabular}


Table 2. Residential and workplace exposure to natives $\left({ }_{x} P_{y}^{*}\right)$ by year of arrival, region of residence and immigrant origin.

\begin{tabular}{|c|c|c|c|c|c|c|c|c|c|c|}
\hline \multirow{2}{*}{$\begin{array}{c}\text { Year } \\
\text { of } \\
\text { arrival }\end{array}$} & \multirow{2}{*}{ Region } & \multirow{2}{*}{ Origin $^{a}$} & \multicolumn{4}{|c|}{ Residence } & \multicolumn{4}{|c|}{ Workplace } \\
\hline & & & 1990 & 1995 & 2000 & 2005 & 1990 & 1995 & 2000 & 2005 \\
\hline \multirow{10}{*}{ ஓे } & \multirow{2}{*}{ Stockholm } & GN & 80 & 76 & 76 & 75 & 82 & 84 & 82 & 81 \\
\hline & & GS & 74 & 66 & 65 & 65 & 83 & 83 & 80 & 78 \\
\hline & \multirow{2}{*}{ Gothenburg } & GN & 79 & 77 & 78 & 78 & 84 & 87 & 85 & 84 \\
\hline & & GS & 77 & 66 & 65 & 67 & 86 & 86 & 81 & 80 \\
\hline & \multirow{2}{*}{ Malmö } & GN & 81 & 76 & 75 & 74 & 87 & 88 & 85 & 83 \\
\hline & & GS & 76 & 67 & 65 & 65 & 87 & 86 & 83 & 82 \\
\hline & \multirow{2}{*}{ Larger regional centres } & GN & 88 & 85 & 85 & 85 & 91 & 92 & 91 & 90 \\
\hline & & GS & 87 & 80 & 80 & 79 & 91 & 92 & 90 & 89 \\
\hline & \multirow{2}{*}{ Rest of Sweden } & GN & 89 & 88 & 88 & 87 & 91 & 91 & 90 & 89 \\
\hline & & GS & 90 & 88 & 86 & 86 & 92 & 92 & 90 & 89 \\
\hline \multirow{10}{*}{ } & \multirow{2}{*}{ Stockholm } & GN & & 78 & 75 & 75 & & 85 & 82 & 81 \\
\hline & & GS & & 70 & 65 & 65 & & 84 & 80 & 79 \\
\hline & \multirow{2}{*}{ Gothenburg } & GN & & 76 & 72 & 72 & & 88 & 85 & 84 \\
\hline & & GS & & 68 & 63 & 65 & & 88 & 82 & 81 \\
\hline & \multirow{2}{*}{ Malmö } & GN & & 76 & 72 & 72 & & 87 & 85 & 83 \\
\hline & & GS & & 68 & 64 & 65 & & 85 & 83 & 81 \\
\hline & \multirow{2}{*}{ Larger regional centres } & GN & & 84 & 82 & 81 & & 92 & 90 & 90 \\
\hline & & GS & & 81 & 79 & 78 & & 91 & 89 & 89 \\
\hline & \multirow{2}{*}{ Rest of Sweden } & GN & & 88 & 86 & 85 & & 91 & 90 & 89 \\
\hline & & GS & & 90 & 89 & 88 & & 92 & 92 & 91 \\
\hline \multirow{10}{*}{ ঠ্ণ } & \multirow{2}{*}{ Stockholm } & GN & & & 79 & 76 & & & 83 & 82 \\
\hline & & GS & & & 67 & 65 & & & 82 & 79 \\
\hline & \multirow{2}{*}{ Gothenburg } & GN & & & 78 & 75 & & & 86 & 85 \\
\hline & & GS & & & 61 & 60 & & & 82 & 81 \\
\hline & \multirow{2}{*}{ Malmö } & GN & & & 76 & 74 & & & 86 & 84 \\
\hline & & GS & & & 65 & 63 & & & 84 & 82 \\
\hline & \multirow{2}{*}{ Larger regional centres } & GN & & & 85 & 82 & & & 91 & 90 \\
\hline & & GS & & & 79 & 75 & & & 90 & 88 \\
\hline & \multirow{2}{*}{ Rest of Sweden } & GN & & & 88 & 87 & & & 91 & 90 \\
\hline & & GS & & & 88 & 86 & & & 91 & 92 \\
\hline
\end{tabular}

${ }^{\mathrm{a}}$ GN - Global North; GS - Global South. 
Table 3. Standardised residential and workplace exposure to natives $\left(M_{x} P_{y}^{*}\right)$ by year of arrival, region of residence and immigrant origin.

\begin{tabular}{|c|c|c|c|c|c|c|c|c|c|c|}
\hline \multirow{2}{*}{$\begin{array}{c}\text { Year } \\
\text { of } \\
\text { arrival }\end{array}$} & \multirow{2}{*}{ Region } & \multirow{2}{*}{ Origin $^{a}$} & \multicolumn{4}{|c|}{ Residence } & \multicolumn{4}{|c|}{ Workplace } \\
\hline & & & 1990 & 1995 & 2000 & 2005 & 1990 & 1995 & 2000 & 2005 \\
\hline \multirow{10}{*}{ ڤे } & \multirow{2}{*}{ Stockholm } & GN & 7 & 10 & 9 & 9 & 3 & 2 & 3 & 3 \\
\hline & & GS & 13 & 21 & 22 & 21 & 3 & 4 & 5 & 7 \\
\hline & \multirow{2}{*}{ Gothenburg } & GN & 11 & 12 & 10 & 9 & 6 & 3 & 4 & 4 \\
\hline & & GS & 14 & 25 & 25 & 22 & 3 & 4 & 8 & 9 \\
\hline & \multirow{2}{*}{ Malmö } & GN & 9 & 13 & 13 & 12 & 3 & 3 & 3 & 4 \\
\hline & & GS & 15 & 23 & 25 & 23 & 3 & 5 & 6 & 6 \\
\hline & \multirow{2}{*}{ Larger regional centres } & GN & 6 & 7 & 7 & 6 & 3 & 2 & 2 & 2 \\
\hline & & GS & 7 & 13 & 13 & 13 & 2 & 2 & 3 & 3 \\
\hline & \multirow{2}{*}{ Rest of Sweden } & GN & 5 & 5 & 6 & 6 & 4 & 3 & 4 & 4 \\
\hline & & GS & 4 & 6 & 8 & 7 & 2 & 3 & 4 & 4 \\
\hline \multirow{10}{*}{ ڤू } & \multirow{2}{*}{ Stockholm } & GN & & 8 & 10 & 10 & & 2 & 3 & 3 \\
\hline & & GS & & 17 & 22 & 21 & & 2 & 5 & 6 \\
\hline & \multirow{2}{*}{ Gothenburg } & GN & & 13 & 17 & 16 & & 2 & 3 & 4 \\
\hline & & GS & & 23 & 27 & 25 & & 2 & 7 & 8 \\
\hline & \multirow{2}{*}{ Malmö } & GN & & 13 & 16 & 15 & & 4 & 4 & 4 \\
\hline & & GS & & 22 & 25 & 23 & & 6 & 6 & 7 \\
\hline & \multirow{2}{*}{ Larger regional centres } & GN & & 8 & 10 & 10 & & 2 & 2 & 2 \\
\hline & & GS & & 11 & 14 & 14 & & 2 & 3 & 4 \\
\hline & \multirow{2}{*}{ Rest of Sweden } & GN & & 6 & 7 & 8 & & 3 & 4 & 4 \\
\hline & & GS & & 4 & 5 & 4 & & 2 & 1 & 2 \\
\hline \multirow{10}{*}{ ষ্ণ } & \multirow{2}{*}{ Stockholm } & GN & & & 6 & 8 & & & 2 & 2 \\
\hline & & GS & & & 19 & 22 & & & 3 & 5 \\
\hline & \multirow{2}{*}{ Gothenburg } & GN & & & 10 & 12 & & & 2 & 3 \\
\hline & & GS & & & 29 & 30 & & & 7 & 7 \\
\hline & \multirow{2}{*}{ Malmö } & GN & & & 11 & 12 & & & 3 & 3 \\
\hline & & GS & & & 24 & 25 & & & 5 & 6 \\
\hline & \multirow{2}{*}{ Larger regional centres } & GN & & & 7 & 9 & & & 2 & 2 \\
\hline & & GS & & & 14 & 17 & & & 3 & 4 \\
\hline & \multirow{2}{*}{ Rest of Sweden } & GN & & & 5 & 6 & & & 3 & 3 \\
\hline & & GS & & & 6 & 7 & & & 3 & 2 \\
\hline
\end{tabular}

${ }^{\mathrm{a}}$ GN - Global North; GS - Global South. 
Table 4. Determinants of immigrant exposure to natives at current workplace five years after arrival in Sweden, odds ratios.

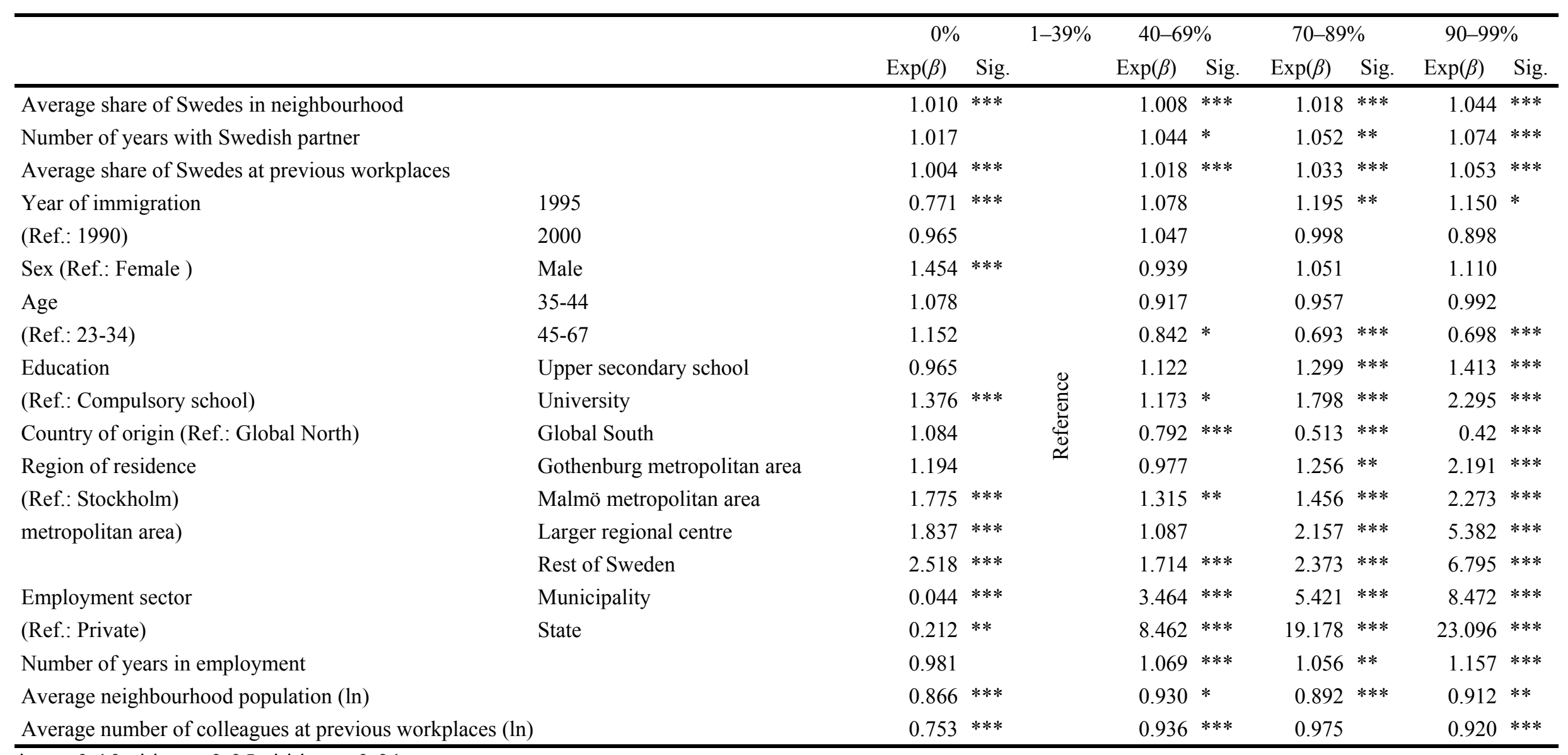

$* \mathrm{p}<0.10 ; * * \mathrm{p}<0.05 ; * * * \mathrm{p}<0.01$.

Nagelkerke pseudo $R^{2}: 0.400$. 